\title{
Evaluation of protein and mineral nutrients in cattle hide scraps used for treating children with kwashiorkor in Bukavu
}

\begin{abstract}
Kwashiorkor is an appalling state of malnutrition that strikes many children under five in developing countries including the Democratic Republic of Congo. Because of poverty, local population is using beef skins hide (cowhide or oxhide) scrapings, named "Nkulo" in Bukavu city, to combat this condition. This study aimed at analyzing quantitatively the content of Nkulo in mineral and protein-energetic nutrients to verify whether it is suitable for such a purpose. Five samples were purchased in different open markets of the city. The protein content was evaluated as total nitrogen by Kjedhal method whereas the mineral content was determined by Atomic Absorption Spectrometer and X-Ray Spectrofluorometer. On average the yield in proteins was $53.5 \pm 2.9$ percent. The minerals in appreciable concentration were $\mathrm{Fe}(50 \mathrm{mg} / 100 \mathrm{~g}) ; \mathrm{Si}(19 \mathrm{mg} / 100 \mathrm{~g}) ; \mathrm{Sb}(18 \mathrm{mg} / 100 \mathrm{~g})$; $\mathrm{Ca}(16 \mathrm{mg} / 100 \mathrm{~g}) ; \mathrm{Sn}(13 \mathrm{mg} / 100 \mathrm{~g}) ; \mathrm{Cr}(11 \mathrm{mg} / 100 \mathrm{~g}) ; \mathrm{Ni}(10 \mathrm{mg} / 100 \mathrm{~g}) ; \mathrm{K}(10 \mathrm{mg} / 100 \mathrm{~g})$; $\mathrm{P}(5 \mathrm{mg} / 100 \mathrm{~g} /) ; \mathrm{Ti}(3 \mathrm{mg} / 100 \mathrm{~g}) ; \mathrm{S}(1 \mathrm{mg} / 100 \mathrm{~g}) ; \mathrm{Cu}(1 / 100 \mathrm{~g}) ; \mathrm{Zn}(0.7 \mathrm{mg} / 100 \mathrm{~g})$. Other elements were found in less than $0.7 \mathrm{mg} / 100 \mathrm{~g}$. The high concentration in proteins and iron may justify the use of Nkulo for protein linked malnutrition and anaemia. The concentration in heavy metals was inferior to maximal admissible levels. However the quality of storage and packaging should be improved to prevent possible fungal contamination. Local pharmacists and nutritionists are invited to assist in preparing innovative formula.
\end{abstract}

Keywords: child, malnutrition, kwashiorkor, cowhide, micronutrient, protein, bukavu
Volume 8 Issue I - 2018

\author{
F Makelele Bwirhonde,' G Beli Bulambo,' \\ Fidele Mutelezi,' F Mushakalusi Kasai,' J \\ Ntokamunda Kadima ${ }^{2}$ \\ 'Department of Pharmacy, University of Kisangani, Africa \\ ${ }^{2}$ Department of Pharmacy, University of Rwanda, Africa
}

Correspondence: J Nokamunda Kadima, School of Medicine and Pharmacy, Department of Pharmacy, University of Rwanda, Rwanda,Africa, Email kadima48@yahoo.com

Received: November 24, 2017 | Published: February 05, 2018
Abbreviations: MMN, multiple micronutrients; MNDs, micronutrient deficiencies; PEM, protein-energy malnutrition

\section{Introduction}

More than half of the world's diseases can be attributed to unbalanced energy intake and to deficiencies in vitamins and mineral nutrients..$^{1-3}$ Developing countries pay the major tribute of it as they face serious health problems due to undernourishment of children and pregnant women. ${ }^{3}$ Protein-energy malnutrition (PEM), also known as protein-calorie malnutrition, is currently the most serious nutritional problem faced by Africa and other developing regions. The two severe clinical forms of PEM are kwashiorkor and marasmus. ${ }^{4}$ Kwashorkor is mainly a protein deficiency and marasmus an energy deficiency (calories). Beside those two forms, there are many intermediate forms, such stunting which is a short linear growth not translated in direct clinical disease. ${ }^{3,4}$ Children who develop kwashiorkor may not grow or develop properly and may remain stunted for the rest of their lives.

Kwashiorkor most commonly affects children one to three years old, after weaning. In kwashiorkor, the diet may be enough to calm hunger but generally very deficient in protein and energy. Alongside the food deficiency, other diseases may also play an important role in precipitating the establishment of frank kwashiorkor in the already malnourished child. ${ }^{2,4}$ The most important are gastrointestinal infections that cause diarrhoea and impede normal absorption, and sometimes also vomiting, resulting in loss of food. ${ }^{4,5}$ Intestinal worms and other parasites may be important agents. It is also known that measles, pertussis and other infectious diseases are frequently the immediate causes of kwashiorkor. ${ }^{4,5}$ Kwashiorkor is also known as "edematous malnutrition" because of its association with edema. The symptoms of kwashiorkor include change in skin and hair color (to a rust color) and texture, fatigue, diarrhea, loss of muscle mass, failure to grow or gain weight, edema (swelling) of the ankles, feet, and belly, damaged immune system, which can lead to more frequent and severe infections, irritability, flaky rash, shock. There can be serious complications when treatment is delayed, including coma, shock, and permanent mental and physical disabilities. ${ }^{4,5}$ Children who have kwashiorkor typically have an extremely emaciated appearance in all body parts except their ankles, feet, and belly, which swell with fluid.

Most people affected by kwashiorkor recover fully if they are treated early. Treatment involves introducing extra calories and protein into the diet. Generally, this management is based on dietary advice, oral nutritional supplements and artificial nutrition. ${ }^{4,5}$ Dairy products, meat, meat products, fish and fish products and eggs are rich in proteins and rich in essential amino acids which can easily be assimilated (more than $90 \%$ true digestibility), while cereals, legumes, green vegetables, tubers, roots and fruits have a decreasing protein content, but are rich in non-essential amino acids and must be prepared to improve assimilation, since their true digestibility is less than $90 \%{ }^{6-8}$ In developed countries, pharmaceutical-grade and standardized nutrients called nutraceuticals are now available as supplements., ${ }^{910}$ In the US, "nutraceuticals" are regulated as dietary supplements and food additives ${ }^{10}$ and not as a separate regulatory category. This strategy is out of reach for poor families. Kwashiorkor is also triggered by micronutrient deficiencies (MNDs) or lack 
of essential vitamins and minerals which are often referred to as 'hidden hunger' because they develop gradually over time. Mineral and vitamins deficiencies are especially common due to the low dietary intake of enriched foods and inadequate absorption caused by diarrhoea. To help mitigating the impact of malnutrition on the health and growth of infants, UNICEF recommends fortifying their foods with multiple micronutrient (MMN) preparations. ${ }^{11}$ One systematic review of scientific controlled studies has shown that dispersible micronutrient preparations for home fortification reduce anaemia by $34 \%$, iron deficiency anaemia by $57 \%$ and retinol deficiency by $21 \% .{ }^{12}$ Our previous study in Kisangani, demonstrated that UNICEF intervention with Multiple Micronutrient powder had some benefits in reducing stunting. ${ }^{13}$

In Bukavu city (DRC), malnutrition in children is also elevate as in many parts of DRC due to poverty and bad quality of food given to children. The number of kwashiorkor children under 5years is also high. For adults, the basal diet consists mainly of corn and cassava flours and vegetables while meat is seldom in poor families. Children are fed on corn, sorghum or cassava porridge alongside breastfeeding.

A kind of craft nutraceuticals based on cowhide and bull hide scrapings, traditionally called Nkulo, circulate on the market to treat children suffering from kwashiorkor. Cattle hide, popularly known as "ponmo" in South-Western Nigeria, and "welle" in Southern Ghana is considered as a great delicacy in several parts of Africa. ${ }^{14-16}$ In Ghana, and other African countries, singeing is preferred because it maintains the carcass hide for consumption and evokes meat flavors that are highly acceptable. ${ }^{14}$ Nkulo is prepared in different way to make it suitable for treating malnutrition in children and adolescents suffering from kwashiorkor. To obtain Nkulo, oxen skins generally purchased from slaughterhouses are washed with enough water, sunny dried, and then soaked in water for a minimum of 3 days and dried again. Then, the inside of the skin is scraped with a suitable knife. The scraps are packaged in plastic containers. The animals are often 2-3years old at slaughtering. But questions about the quality and the nutritional value of Nkulo arise. This work therefore aimed to analyze the content of Nkulo in essential minerals and proteins in order to approve its use.

\section{Material and methods}

\section{Cowhide scrapings samples (Nkulo)}

Five samples of Nkulo were bought from different markets in Bukavu (Nyawera, Kadutu, Kasoko Camp Saio, Mashinji, and Essence). The selection of the outlet sites was done in a random way. All the samples had the same appearance (wood chips), same smell (characteristic) and same taste (cooked meat), but they differed on the colour (Figure 1). Samples 1, 2, 3 were yellowish and samples 4,5 whitish. Yellowish coloration is characteristic of scrapings from the bull (male) while whitish staining is characteristic of scrapings of cow (female). The samples were ground using mortar and pestle to increase the contact area before analysis. Nkulo is consumed either alone or as fortification of other foods. Generally, 2 to 3 soup spoons are added to corn or cassava flour porridge.

\section{Instruments and chemicals}

The analysis consisted of measuring total protein content by Kjeldahl procedure, sodium by Atomic Absorption Spectrometer (Variant) and various oligo-elements by X-ray fluorescence spectrophotometer (EXAMINER). The main chemicals used were GR from PROLABO International (Belgium), BDOM-Bukavu, PANREAC QUIMICA SAU (Spain) and Geldenaakbaan-UCB (Leuven-Belgium).

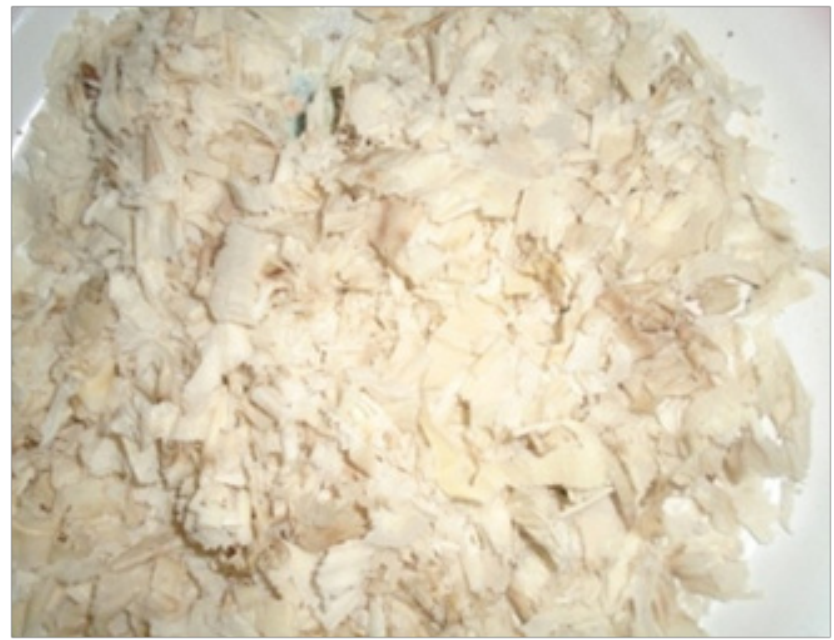

Figure I Specimen of nkulo.

\section{Determination of proteins by Kjeldahl digestion meth-} od I 7

The digestion converts any nitrogen in the food (other than that which is in the form of nitrates or nitrites) into ammonia, and other organic matter to $\mathrm{CO}_{2}$ and $\mathrm{H}_{2} 0$. Ammonia gas is not liberated in an acid solution because the ammonia is in the form of the ammonium ion $\left(\mathrm{NH}_{4}^{+}\right)$which binds to the sulfate ion $\left(\mathrm{SO}_{4}^{2-}\right)$ and thus remains in solution. Practically, an aliquot of $2 \mathrm{~g}$ of sample is digested into the Kjeldahl flask at $330^{\circ} \mathrm{C}$ with $20 \mathrm{ml}$ of sulphuric acid $98 \%$ in the presence of copper sulphate $(1.5 \mathrm{~g})$ and selenium $(1.5 \mathrm{~g})$ as catalytic. When cool, the solution is transferred into a $100 \mathrm{ml}$ flask and diluted to gauge with distilled water. Then $20 \mathrm{ml}$ of the digest is mixed with $10 \mathrm{ml}$ of $\mathrm{NaOH} 33 \%$ and $200 \mathrm{ml}$ of distilled water. The mixture is distillate and collected in $20 \mathrm{ml}$ of $\mathrm{HCl} 0.1 \mathrm{~N}$ in the presence of 2 to 3 drops of mixed indicator. $\mathrm{NH}_{3}$ stripped in steam was titrated with $0.1 \mathrm{~N} \mathrm{NaOH}$ solution until discoloration. The content of nitrogen in percentage per $100 \mathrm{~g}$ of the sample was estimated as following:

$$
\% \text { TotalNitrogen }=100 \frac{(V a-V b) * 0.0014008^{*} n}{P}
$$

Va: Volume of $\mathrm{HCl} 0.1 \mathrm{~N} ; \mathrm{V}_{\mathrm{b}}$ : Volume of $\mathrm{NaOH} 0.1 \mathrm{~N} ; \mathrm{P}$ : Weight of the sample; n: Dilution Factor

To obtain the crude protein content, the total nitrogen content was multiplied by a conversion factor 6.25 .

\section{Determination of mineral elements by X-Ray fluores- cence spectrometer 18}

Aliquots of $2 \mathrm{~g}$ for each sample were incinerated in crucibles at $800^{\circ} \mathrm{C}$ for 1 hour (Barume K, 1989, OCC-RDC, 1998). Each ash was quantitatively collected and put in appropriated sample bags. Each bag was transferred to XRF-Examiner and measured according to the manufacturer's procedure. The concentration of each element is given as percent (g of element per 100g of ash) or in ppm (parts per million). The mineral concentration (E) as percent per $100 \mathrm{~g}$ of cowhide sample was calculated as:

$$
E=\frac{T x A}{100}
$$

A: Percentage of ash; T: Element in percent per ash; E: Element in percent per sample 


\section{Determination of sodium by atomic absorption I 9-2 I}

$1 \mathrm{~g}$ of sample was mixed with $25 \mathrm{ml}$ of digestive solution heated in oven at $95^{\circ} \mathrm{C}$ for 2 hours. When cool, distilled water was added qs $100 \mathrm{ml}$ and then filtered; 1/100 dilution was made with $\mathrm{SrCl}_{2}$ solution.

\section{Results}

Table 1 compiles the findings in proteins, total ash and mineral nutrients content. On average the proteins yielded $52.4 \pm 1.9 \mathrm{~g} / 100 \mathrm{~g}$ $(50.8-55.8 \%)$. There was not significant variation between the 5 samples. The total ash was less than $1 \%(0.2 \%-0.36 \%)$. The elements in appreciable concentrations expressed in $(\mathrm{mg} / 100 \mathrm{~g})$ were: $\mathrm{Fe}(49.0 \pm 21.8) ; \mathrm{Si}(19.0 \pm 11.7) ; \mathrm{Sb}(18.9 \pm 7.4) ; \mathrm{Ca}(16.6 \pm 4.1)$; $\mathrm{Sn}(13.3 \pm 5.4) ; \quad \mathrm{Cr}(11.0 \pm 16.3) ; \quad \mathrm{Ni}(10.1 \pm 18.9) ; \quad \mathrm{K}(10.0 \pm 6.7)$; $\mathrm{P}(5.0 \pm 6.3) ; \mathrm{Ti}(2.6 \pm 1.0) ; \mathrm{S}(1.3 \pm 0.6) ; \mathrm{Cu}(1.2 \pm 1.2) ; \mathrm{Zn}(0.68 \pm 0.56)$. Other elements like $\mathrm{Cd}, \mathrm{Pb}, \mathrm{Mn}, \mathrm{Ba}, \mathrm{Mo}, \mathrm{As}, \mathrm{Sr}, \mathrm{Co}, \mathrm{Zr}, \mathrm{Rb}$ were found in concentrations less than $7 \mathrm{mg} / \mathrm{kg}$. For minerals, there were some significant differences between the 5 samples. For example, Nickel and Copper were detected in all samples but sample-1; Silicium has been detected in all samples but sample-2. The concentration of sodium was determined only in sample-1 by atomic absorption method and was $0.35 \mathrm{mg} / 100 \mathrm{~g}$.

Table I Crude proteins content (\%) and mineral nutrients ( $\mathrm{mg} / \mathrm{l00g})$ in "Nkulo"

\begin{tabular}{|c|c|c|c|c|c|c|c|c|}
\hline \multirow{2}{*}{ Elements } & \multirow{2}{*}{$\begin{array}{l}\text { Mean士SD } \\
S_{1}-S_{5}\end{array}$} & \multicolumn{4}{|c|}{ Yellowish samples } & \multicolumn{3}{|c|}{ Whitish samples } \\
\hline & & $\mathbf{s}_{1}$ & $\mathbf{S}_{2}$ & $\mathbf{S}_{3}$ & s/Mean & $\mathbf{S}_{4}$ & $\mathbf{S}_{5}$ & s/Mean \\
\hline Proteins (\%) & $52.4 \pm 2.1$ & 50.8 & 55.8 & 51.1 & 52.6 & 51.1 & 53.2 & 52.4 \\
\hline Ash (mg//00g) & $253.8 \pm 64.3$ & 223.9 & 360.1 & 216.9 & 267.0 & 267.2 & 201.0 & 256.0 \\
\hline $\mathrm{Fe}$ & $49.0 \pm 21.8$ & 24.6 & 40.7 & 36.3 & 33.8 & 76.6 & 66.8 & 71.7 \\
\hline $\mathrm{Si}$ & $19.0 \pm 11.7$ & 21.5 & $\mathrm{Nd}$ & 17.4 & 12.9 & 30.8 & 25.4 & 28.1 \\
\hline $\mathrm{Sb}$ & $18.9 \pm 7.4$ & 26.5 & 26.7 & 16.7 & 23.3 & 14.7 & 9.9 & 12.3 \\
\hline $\mathrm{Ca}$ & $16.6 \pm 4.1$ & 17.2 & 22.1 & 14.7 & 18.0 & 18.0 & 11.1 & 14.6 \\
\hline Sn & $13.3 \pm 5.4$ & 12.0 & 22.6 & 10.4 & 15.0 & 12.4 & 8.9 & 10.7 \\
\hline $\mathrm{Cr}$ & $11.0 \pm 16.3$ & 1.2 & 0.16 & 0.1 & 0.5 & 16.2 & 37.5 & 26.9 \\
\hline K & $10.1 \pm 6.8$ & 10.9 & 20.9 & 4.3 & 12.1 & 9.6 & 4.4 & 7.0 \\
\hline$P$ & $5.0 \pm 6.4$ & 2.9 & 1.8 & 1.2 & 1.9 & 16.3 & 2.8 & 9.6 \\
\hline $\mathrm{Ti}$ & $2.6 \pm 1.1$ & 1.2 & 4.2 & 2.5 & 2.6 & 2.2 & 2.8 & 2.5 \\
\hline $\mathrm{Ni}$ & $2.3 \pm 2.3$ & $\mathrm{Nd}$ & 0.6 & 1.3 & 0.6 & 4.4 & 5.1 & 4.7 \\
\hline $\mathrm{Cu}$ & $1.2 \pm 1.3$ & $\mathrm{Nd}$ & 3.0 & 0.2 & I.I & 1.8 & 1.1 & 1.4 \\
\hline$S$ & $1.2 \pm 0.8$ & 1.5 & 2.3 & 0.6 & 1.5 & 0.1 & 1.2 & 0.6 \\
\hline $\mathrm{Zn}$ & $0.7 \pm 0.5$ & 1.4 & 0.9 & 0.7 & 1.0 & 0.3 & 0.07 & 0.2 \\
\hline $\mathrm{Cd}$ & $0.5 \pm 0.4$ & 0.5 & 0.5 & 0.05 & 0.3 & 0.4 & 1.2 & 0.8 \\
\hline $\mathrm{Pb}$ & $0.4 \pm 0.6$ & 0.03 & 1.6 & 0.04 & 0.5 & 0.09 & 0.1 & 0.1 \\
\hline$M n$ & $0.3 \pm 0.4$ & $\mathrm{Nd}$ & 0.3 & 0.3 & 0.2 & 1.0 & $\mathrm{Nd}$ & 0.5 \\
\hline $\mathrm{Ba}$ & $0.2 \pm 0.2$ & 0.4 & 0.4 & 0.2 & 0.3 & $\mathrm{Nd}$ & 0.06 & 0.03 \\
\hline Mo & $0.1 \pm 0.2$ & 0.02 & 0.02 & $\mathrm{Nd}$ & 0.01 & 0.2 & 0.3 & 0.3 \\
\hline As & $0.1 \pm 0.2$ & $\mathrm{Nd}$ & 0.5 & 0.04 & 0.2 & 0.04 & 0.02 & 0.03 \\
\hline $\mathrm{Sr}$ & $0.08 \pm 0.03$ & 0.07 & 0.1 & 0.1 & 0.09 & 0.06 & 0.04 & 0.05 \\
\hline Co & $0.07 \pm 0.09$ & $\mathrm{Nd}$ & 0.2 & 0.07 & 0.10 & 0.05 & 0.02 & 0.04 \\
\hline $\mathrm{Zr}$ & $0.06 \pm 0.00$ & 0.05 & 0.06 & 0.05 & 0.05 & 0.06 & 0.05 & 0.06 \\
\hline $\mathrm{Rb}$ & $0.03 \pm 0.02$ & $\mathrm{Nd}$ & 0.05 & 0.05 & 0.03 & 0.02 & 0.01 & 0.02 \\
\hline
\end{tabular}




\section{Discussion}

For proteins, the difference between whitish hide and yellowish hide was not significant. The protein content in Nkulo is comparable to the content in cow meat on the basis of dry matter. Normally, the moisture of cattle meat is between $50 \%$ and $70 \%$, the protein content is $19 \%$ to $22 \%$, while fat content varies from $2.7 \%$ to $8.8 \%{ }^{22}$ The conversion to dry matter would give $42 \%$ to $63 \%$ of proteins and $5 \%$ to $25 \%$ of fat. In unsinged and singed cowhide "welle" consumed in Ghana, the protein content was evaluated at 85.6 to $93.6 \%$ respectively. ${ }^{14}$

The total ash and the content of common nutritive elements but iron were significantly low in cowhide scraps compared to normal meat $(0.7 \text { to } 2 \%)^{22,23}$ or to welle $(0.83-1.67 \%){ }^{14}$

For some elements, the concentrations were significantly different between whitish and yellowish samples; e.g. Fe (71.7vs. 33.8 $\mathrm{mg} / 100 \mathrm{~g}) ; \mathrm{Cr}(0.49$ vs. $28.9 \mathrm{mg} / 100 \mathrm{~g}) ; \mathrm{K}(12$ vs. $7 \mathrm{mg} / 100 \mathrm{mg})$. The study of welle in Ghana found comparable values with this study. The levels of heavy metal in fermented and singed cattle hide were: $\mathrm{Fe}$ ( 7.3 $-26.4 \mathrm{mg} / 100 \mathrm{~g}) ; \mathrm{Mn}(0.58-4.04 \mathrm{mg} / 100 \mathrm{~g}) ; \mathrm{Cu}(0.019-2.31 \mathrm{mg} / 100 \mathrm{~g})$; and $\mathrm{Zn}(0.33-3.53 \mathrm{mg} / 100 \mathrm{~g})$; the contents of $\mathrm{Pb}$ and $\mathrm{Cd}$ were below detectable limits. The procedure of preparation by washing in water before may explain the low content in minerals. The variations indicate that either the procedure of preparation is not standardized or the content differs from animal to animal, not withdrawing the analytical errors. The levels of mineral nutrients found in Nkulo are generally quite low when compared to some reported cases in meat products. ${ }^{24,25}$ The complexity of minerals detected may reflect the composition of the soil and animal food taken. ${ }^{26}$ Bukavu is a region known very rich in all kind of minerals.

Nkulo preparations contain iron, zinc, cobalt, copper which are generally incorporated in multiple micronutrient powders used as foods fortification. ${ }^{27}$ The observed metal levels were generally far below the maximum permissible levels (MPLs) in meats. The (USDA, 2006) reported the maximum MPLs of $\mathrm{Cu}(0.2 \mathrm{mg} / \mathrm{Kg}), \mathrm{Zn}(0.5 \mathrm{mg} /$ $\mathrm{Kg}), \mathrm{Cd}(0.05 \mathrm{mg} / \mathrm{Kg})$ and $\mathrm{Pb}(0.1 \mathrm{mg} / \mathrm{Kg})$. However with regards to the observed levels of $\mathrm{Fe}, \mathrm{Si}, \mathrm{Sb}, \mathrm{Sn}$, and $\mathrm{Cr}$ above $100 \mathrm{mg} / \mathrm{Kg}$, it is not clear whether the recorded values in this study would constitute significant health implications for consumers because no MPLs are assigned. ${ }^{28-30}$

Studies have shown that high levels of minerals in the feed do not necessarily increase the level of that mineral in the flesh and there is a complex inter-relation between minerals. ${ }^{30}$ Two relationships exist among the trace elements, antagonistic and synergistic, which occur at two levels, absorptive and metabolic. Excess intake of a single element can decrease the intestinal absorption of another element. As an example, a high intake of calcium depresses intestinal zinc absorption, while an excess intake of zinc can depress copper absorption. An excess of one element interferes with the metabolic functions of another or contributes to its excretion due to compartmental displacement. This is seen with zinc and copper, cadmium and zinc, iron and copper, calcium, magnesium and phosphorus. Synergism between the elements occurs largely on a metabolic level. As an example, iron and copper are synergistic in that sufficient copper is required for iron utilization.

The synergism between calcium, magnesium and phosphorus is well known due to their requirement in the maintenance and structure of osseous tissue. Other mineral synergisms include $\mathrm{Cu}-\mathrm{Fe}-\mathrm{Co}-\mathrm{Ca}-$
$\mathrm{Na}-\mathrm{Se}$ ) and $\mathrm{Zn}-\mathrm{K}-\mathrm{Mg}-\mathrm{Mn}-\mathrm{Cr}-\mathrm{P})$. A third relationship is also noted, wherein a deficient intake of an element can allow toxic accumulation of another element. Small amounts of cadmium intake can accumulate to a point of toxicity in the presence of marginal or deficient zinc intake. Lead toxicity can occur with insufficient calcium or iron intake, and iron toxicity can develop in the presence of a copper deficiency. A fourth relationship can also be seen when an excessive intake of a single element produces a deficiency of a synergistic element. Manganese by interfering with magnesium can result in excessive potassium and sodium accumulation.

\section{Conclusion}

The high concentration in proteins and iron may justify the use of cowhide scraps ("Nkulo") for protein linked malnutrition and anaemia. The concentration in heavy metals was inferior to maximal admissible levels. However the quality of storage and packaging should be improved to prevent possible fungal contamination. Local pharmacists and nutritionists are invited to assist in preparing innovative formula.

\section{Acknowledgments}

Author declares no acknowledgment.

\section{Conflict of interest}

Author declares no conflict of interest.

\section{References}

1. Deficiencies in vitamins and mineral nutrients. FAO; 2017.

2. Qu'est-ce que la dénutrition. 2017.

3. Black RE, Walker SP, Bhutta ZA, et al. Maternal and child undernutrition and overweight in low-income and middle-income countries. Lancet 2013;382(9890):427-451.

4. What Is Kwashiorkor. 2017.

5. Kwashiorkor. NHS. 2017

6. Jay R Hoffman JR, Falvo MJ. Protein - Which is Best? J Sports Sci Med. 2004;3(3):118-130.

7. Bhutta Z. Protein: digestibility and availability. In: M Sadler, J Strain, B Caballero, editors. Encyclopedia of Human Nutrition. San Diego: Academic Press; 1999. p. 1646-1656.

8. Schaafsma G. The Protein Digestibility-Corrected Amino Acid Score. $J$ Nutr. 2000;130(7):1865S-18 67S.

9. Bull E, Rapport L, Lockwood B. Neutraceuticals. The Pharmaceutical Journal. 2000.

10. Cockbill CA. Food law and functional foods. Br Food J. 1994;96(3):3-4.

11. Micronutrient. UNICEF. 2016.

12. Bhutta ZA, Das JK, Rizvi A, et al. Evidence-based interventions for improvement of maternal and child nutrition: what can be done and at what cost? Lancet. 2013;382(9890):452-477.

13. Mukunda FL, Kasai ET, Opara JA, et al. Effectiveness of UNICEF Multiple Micronutrient Powder on Child Stunting Rate and Influencing Factors in Kisangani. European Journal of Nutrition \& Food Safety. 2017;7(3):179-188.

14. Akwetey WY, Eremong DC Donkoh. Chemical and Nutrient Composition of Cattle Hide ("Welle") Using Different Processing Methods A. $J$ Anim Sci Adv. 2013;3(4):176-180. 
15. Obiri-Danso K, Hogarh JN, Antwi-Agyei P. Assessment of contamination of singed hides from cattle and goats by heavy metals in Ghana. African Journal of Environmental Science and Technology. 2008;2(8):217-221.

16. Okiel W, Ogunlesi M, Alabi F, et al. Determination of toxic metal concentrations in flame treated meat products, ponmo. African Journal of Biochemistry Research. 2009;3(10):332-339.

17. Analytical protocol for agro-food products. OCC-Office Congolais de controle, Kinshasa/RDC, Africa; 1998.

18. Use of spectrophotometer -XRF-Examiner. OCC- Office Congolais de contrôle, Bukavu/RDC, Africa; 2012.

19. Association of Analytical Chemists. $A O A C$. 15th ed. Arlington, VA, US 1990.

20. Introducing Atomic Absorption Analysis. Australia: Varian Australia Pty Ltd; 1997.

21. Parkinson JA, Allen SE. A wet oxidation procedure suitable for the determination of nitrogen and mineral nutrients in biological materials. Commun. Soil Sci Plant anal. 1975;6(1):1-11.

22. Meat, fat and other edible carcass parts. FAO
23. Sinclair A, Mann N, O Connell S. The nutrient composition of Australian beef and lamb. Melbourne: RMIT, 1999.

24. Williams PG. Nutritional composition of red meat. Australia: University of Wollongong; 2007.

25. Leita L, Enne G, De Nobili M, et al. Heavy metal bioaccumulation in lamb and sheep bred in smelting and mining areas of South Western Sardinia, Italy. Food Science and Technology. 1991;24:125-127.

26. Codex A. General standard for contaminants and toxins in food and feed (codex stan 193-1995). 2017.

27. Meat Food Products Order (MFPO1973). Food Safety and Standards Authority of India. 2017

28. Cai Q, Long M, Lui J, et al. Correlation between heavy metal concentration in cattle tissues and rearing environment. Chinese $J$ of Ecol. 2008;27(2):202-207.

29. Specific maximum levels of contaminants in foods. USDA. Foreign Agric services GAIN Report. 2006

30. Watts DL. Nutrient Interrelationships Minerals -Vitamins- Endocrines. Journal of Orthomolecular Medicine. 1990;5(1):11-19. 